НАУКОВИЙ ВІСНИК

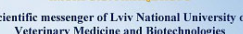

110

(5)

$\int=$

СEPI: ВетеРИнАРН НАУКИ
Науковий вісник Аьвівського національного університету ветеринарної медицини та біотехнологій імені С.3. Гжицького. Серія: Ветеринарні науки

Scientific Messenger of Lviv National University of Veterinary Medicine and Biotechnologies. Series: Veterinary sciences

UDC 619:612.129:636.085.8:636.4

\title{
System of antioxidant protection of the body of piglets under the action of feed additive "Sylimevit"
}

\author{
L. V. Vyslotska ${ }^{1}$, B. V. Gutyj ${ }^{1}$, O. V. Kozenko ${ }^{1}$, V. I. Khalak ${ }^{2}$, M. V. Chornyj ${ }^{1}$, T. V. Martyshuk ${ }^{1}$, N. Yu. Krempa ${ }^{1}$, \\ O. Ye. Vozna ${ }^{1}$, V. B. Todoriuk ${ }^{1}$
}

${ }^{1}$ Stepan Gzhytskyi National University of Veterinary Medicine and Biotechnologies Lviv, Ukraine

${ }^{2}$ State Institution Institute of Grain Crops of NAAS of Ukraine, Dnipro, Ukraine

Article info

Received 08.09.2021

Received in revised form 11.10 .2021

Accepted 12.10.2021

Stepan Gzhytskyi National University of Veterinary Medicine and Biotechnologies Lviv, Pekarska Str., 50, Lviv, 79010, Ukraine. Tel.: +38-068-136-20-54 E-mail:bvh@ukr.net

State Institution Institute of grain crops of NAAS, $V$. Vernadsky Str., 14, Dnipro, 49027, Ukraine. Tel.: +38-067-892-44-04 E-mail:v16kh91@gmail.com
Vyslotska L. V., Gutyj B. V., Kozenko O. V., Khalak V. I., Chornyj, M. V. Martyshuk T. V., Krempa N. Yu., Vozna O. Ye., \& Todoriuk V. B. (2021). System of antioxidant protection of the body of piglets under the action of feed additive "Sylimevit". Scientific Messenger of Lviv National University of Veterinary Medicine and Biotechnologies. Series: Veterinary sciences, 23(104), 10-17. doi: $10.32718 /$ nvlvet10402

One of the conditions for obtaining high-quality pig products is the use of feed additives, which contain all the necessary biologically active substances, eliminating their deficiency in feed and acting as catalysts for metabolic processes in pigs. That is why the aim of the study was to study the effect of feed additive "Sylimevit" on the enzymatic and non-enzymatic parts of the antioxidant system of piglets after weaning. Two groups of piglets were formed - control and experimental, in the amount of 10 individuals in each group, selected on the principle of analogues - age, breed and body weight. During the weaning period, the piglets were kept under the sow in special machines, had constant access to the mother, and from the age of 5 days - free access to concentrated feed. Feeding of animals was carried out in accordance with the norms for a given age of pigs. Prior to the study, a clinical and physiological examination of the piglets was performed. Their general condition and activity when eating food were taken into account. On the 28th day of life, the piglets were weaned from the sow and regrouped from different nests in order to be further maintained during the period of fattening and rearing with a change in the structure of the diet, which served as technological stress for the animals. From the age of 5 days, piglets of all groups were fed prestarter feed. Piglets of the experimental group, from 21 to 40 days of age, were additionally fed the feed supplement "Sylimevit" at a dose of $100 \mathrm{mg} / \mathrm{kg}$ body weight per day. Feeding piglets Silimevit feed enhances their antioxidant status. The use of this feed additive in piglets contributed to the activation of both enzymatic and non-enzymatic parts of the antioxidant defense system of piglets after weaning, as indicated by an increase in blood 35-day-old piglets superoxide dismutase activity by $26.9 \%(P<0.001)$, catalase $-41.1 \%(P<0.001)$, glutathione peroxidase - by $52.7 \%(P<0.05)$, glutathione reductase - by $53.5 \%(P<0.05)$, the content of reduced glutathione - by $75 \%(P<0.001)$. This is due to the fact that silimevit contains active substances such as milk thistle and vitamins, which are strong direct-acting antioxidants and directly interact with free radicals and reactive oxygen species.

Key words: oxidative stress, catalase, superoxide dismutase, glutathione peroxidase, glutathione reductase, reduced glutathione.

\section{Система антиоксидантного захисту організму поросят за дії кормової добавки "Силімевіт"}

Л. В. Вислоцька ${ }^{1}$, Б. В. Гутий ${ }^{1}$, О. В. Козенко ${ }^{1}$, В. І. Халак ${ }^{2}$, М. В. Чорний ${ }^{1}$, Т. В. Мартишук ${ }^{1}$, Н. Ю. Кремпа ${ }^{1}$, О. С. Возна ${ }^{1}$ В. Б. Тодорюк ${ }^{1}$

${ }^{1}$ Львівський національний університет ветеринарної медицини та біотехнологій імені С. 3. Гжицького, м. Львів, Україна 


\section{${ }^{2}$ Державна установа “Інститут зернових культур НААН України”, м. Дніпро, Украӥна}

Однією з умов отримання високоякісної продукиії свинарства є застосування кормових добавок, які у своєму складі містять всі необхідні біологічно активні речовини, усуваючи їх дефіцит у кормах та виконуючи роль каталізаторів обмінних процесів в організмі свиней. Саме тому метою проведених досліджень було вивчити вплив кормової добавки “Силімевіт” на ензимну та неензимну ланки антиоксидантної системи організму поросят після відлучення. Було сформовано дві групи поросят - контрольну $i$ дослідну, у кількості 10 особин у кожній групі, підібраних за принципом аналогів - віком, породою і масою тіла. У підсисний період поросята утримувалися під свиноматкою у спечіальних станках, мали постійний доступ до матері, а з 5-добового віку - вільний доступ до концентрованих кормів. Годівля тварин проводилась відповідно до норм для даного віку свиней. Перед проведенням досліджень здійснювали клінічно-фізіологічне обстеження поголів'я поросят. Враховували їхній загальний стан та активність при поїданні корму. На 28 добу життя поросят відлучали від свиноматки та перегруповували з різних гнізд з метою подальшого утримання у період відгодівлі та дорощування зі зміною структури раціону, щзо слугувало технологічним стресом для організму тварин. Починаючи з 5-добового віку поросят усіх груп підгодовували престартерним комбікормом. Поросятам дослідної групи, починаючи з 21- до 40-добового віку, додатково згодовували кормову добавку “Силімевіт” у дозі 100 мг/кг маси тіла на добу. Згодовування поросятам кормової добавки “Силімевіт” сприяє посиленню їхнього антиоксидантного статусу. Застосування поросятам даної кормової добавки сприяло активізації як ензимної, так і неензимної ланки системи антиоксидантного захисту організму поросят після відлучення, на що вказує підвищення в крові 35-добових поросят активності супероксиддисмутази на 26,9 \% (P < 0,001), каталази - на 41,1\% (P<0,001), глутатіонпероксидази - на 52,7\% $(P<0,05)$, глутатіонредуктази - на 53,5\% (P<0,05), вмісту відновленого глутатіону - на $75 \%$ ( $<$ <,001). Це пов 'язано з тим, шуо до складу силімевіту входять такі діючі речовини, як розторопша плямиста та вітаміни, які є сильними антиоксидантами прямої дї та безпосередньо взаємодіють з вільними радикалами та активними формами кисню.

Ключові слова: оксидаційний стрес, каталаза, супероксиддисмутаза, глутатіонпероксидаза, глутатіонредуктаза, відновлений глутатіон.

\section{Вступ}

Свинарство України є однією із важливих галузей тваринництва, яка виробляє найбільшу частину харчових продуктів тваринного походження. Основне місце у розвитку і прогресивному функціонуванні даної галузі займає відтворення свинопоголів'я (Нео et al., 2012; Han et al., 2019; Khalak et al., 2020; 2021). Вагоме значення у даній галузі має забезпечення раціонів свиней регламентованими поживними та біологічно активними речовинами згідно зі встановленими нормами годівлі (Jacela et al., 2010; Ahmad et al., 2011; Ariza-Nieto et al., 2011; Czech et al., 2018; Kramarenko et al., 2018; 2019).

Впровадження інтенсивних технологій у свинарстві передбачає раннє відлучення поросят від свиноматок, що призводить до виникнення так званих технологічних стресів, що в подальшому викликає порушення їхнього метаболічного гомеостазу i посилення в організмі процесів пероксидного окиснення ліпідів (Hedemann \& Jensen, 2004).

При інтенсивному веденні свинарства 3 повідомлень в літературі відомо, що раннє відлучення поросят від свиноматок $\epsilon$ екстремальним подразником, який спричиняє зниження захисно-пристосувальних реакцій організму поросят (Bulter et al., 2006; De Lange et al., 2010; Khalak \& Gutyj, 2020). У результаті цього виникає стресовий стан, що супроводжується затримкою росту, порушенням відтворної здатності та зниженням якості м'ясопродуктів. Водночас важливо зазначити, що розвиток оксидаційного стресу у поросят супроводжується активацією вільнорадикального окиснення ліпідів плазматичних і внутрішньоклітинних мембран гепатоцитів на тлі виснаження захисних протирадикальних систем (Frankic et al., 2010; Gutyj et al., 2017; 2021). Активація процесів пероксидного окиснення ліпідів та утворення великої кількості вільних радикалів призводить не тільки до пошкодження гепатоцитів, а й до змін у клітинах крові - най- більш мобільній системі організму (Khariv et al., 2016; 2017; Ivankiv et al., 2019).

Для зменшення негативної дії технологічного стресу у поросят розробляють та впроваджують ефективні та економічно вигідні засоби. Особливо перспективним у даному напрямі $є$ використання кормових добавок на основі рослинної сировини. $Є$ окремі повідомлення про стимулюючий вплив розторопші плямистої, метіфену, Селену та вітамінів на активність антиоксидантної та гепатопротекторної дії у поросят. Однак комплексне застосування вказаних речовин у складі кормової добавки "Силімевіт" на активність системи антиоксидантного захисту організму відлучених поросят на даний час у науковій літературі висвітлене недостатньо.

Проведення досліджень саме в такому аспекті $€$ актуальним, оскільки відкриває шлях до розробки науково обгрунтованих методів управління адаптаційними процесами у поросят при відлученні. Вирішення цього питання буде покладено в основу створення кормової добавки для запобігання розвитку оксидаційного стресу в поросят при відлученні на основі розторопші плямистої, метіфену, вітамінів А, Е, С та Селену.

Саме тому метою проведених досліджень було вивчити вплив кормової добавки "Силімевіт" на ензимну та неензимну ланки антиоксидантної системи організму поросят після відлучення.

\section{Матеріал та методи досліджень}

Досліди проводились на базі ТОВ “КОШЕТ” Мукачівського району Закарпатської області. Було сформовано дві групи поросят - контрольну (К) і дослідну (Д) в кількості 10 особин у кожній групі, підібраних за принципом аналогів - віком, породою і масою тіла. У підсисний період поросята утримувалися під свиноматкою у спеціальних станках, мали постійний доступ до матері, а з 5-добового віку - вільний доступ 
до концентрованих кормів. Годівля тварин проводилась відповідно до норм для даного віку свиней. Перед проведенням досліджень здійснювали клінічнофізіологічне обстеження поголів'я поросят, враховували їхній загальний стан та активність при поїданні корму. На 28 добу життя поросят відлучали від свиноматки та перегруповували 3 різних гнізд з метою подальшого утримання у період відгодівлі та дорощування зі зміною структури раціону, що слугувало технологічним стресом для організму тварин. Починаючи з 5-добового віку поросят усіх груп підгодовували престартерним комбікормом. Поросятам дослідної групи починаючи з 21- до 40-добового віку додатково згодовували кормову добавку “Силімевіт” у дозі 100 мг/кг маси тіла на добу.

Матеріалом для досліджень була кров, яку відбирали вранці, до годівлі тварин шляхом пункції краніальної порожнистої вени на 20 добу життя (період до відлучення), на 25 добу життя (період до відлучення), на 30 добу життя (2 доба після відлучення), на 35 добу життя (7 доба після відлучення), на 40 добу життя (12 доба після відлучення).

Активність глутатіонпероксидази (ГП, КФ. 1.11.1.9) та глутатіонредуктази (ГР, КФ. 1.6.4.2) визначали за методом В. В. Лемешко і співавт. (1985); активність каталази (КТ; К.Ф. 1.11.1.6) - за методом М. А. Королюк (1988); активність супероксиддисму- тази (СОД, КФ. 1.15.1.1) - за методом Є. Є. Дубініної і співав. (1983).

Експериментальні дослідження проводили відповідно до Закону України "Про захист тварин від жорстокого поводження" від 28.03.2006 р. та правил Свропейської конвенції захисту хребетних тварин, які використовуються в експериментальних та інших наукових цілях від 13.11.1987 р.

Аналіз результатів досліджень проводили за допомогою пакету програм Statistica 6.0. Вірогідність різниць оцінювали за t-критерієм Стьюдента. Результати середніх значень вважали статистично вірогідними при $*_{-} \mathrm{P}<0,05, * *-\mathrm{P}<0,01, * * *_{-} \mathrm{P}<0,001$ (ANOVA).

\section{Результати та їх обговорення}

При дослідженні активності супероксиддисмутази у крові поросят встановлено, що у 20-добових поросят вона була найнижчою, де відповідно становила $16,36 \pm 0,75$ ум. од./хв $\times$ мг білка (рис. 1). На 25-у добу досліду активність даного ензиму дещо зросла і порівняно 3 попередньою добою зросла на 11,7 \%. Після відлучення у крові поросят контрольної групи спостерігали понижену активність СОД, де порівняно із 25 добою досліду активність досліджуваного ензиму знизилася на 14,5 \%. У подальшому активність супероксиддисмутази у крові поросят контрольної групи залишалася низькою на 35 і 40-у добу досліду.

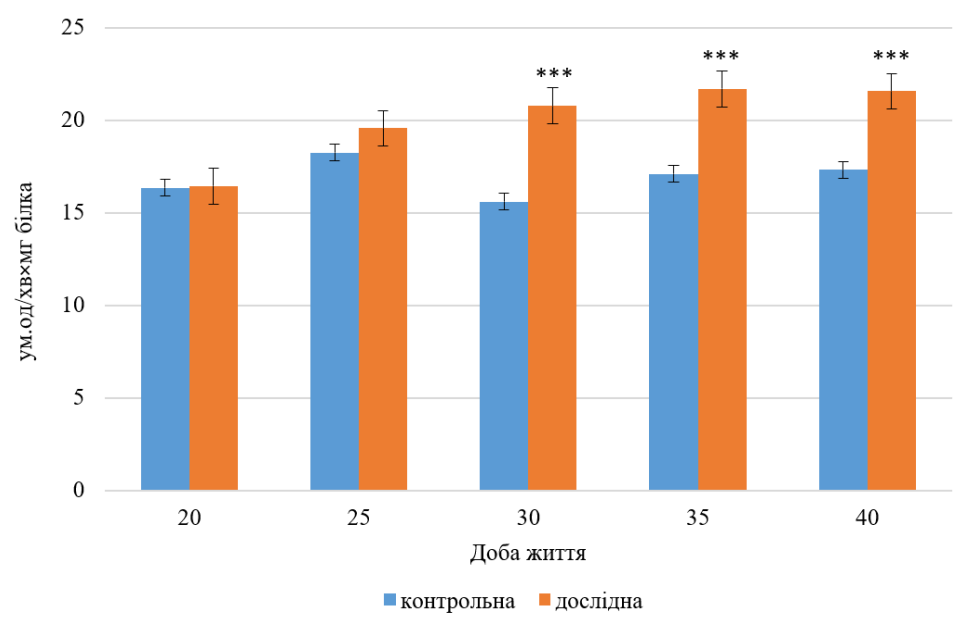

Рис. 1. Активність СОД у крові поросят за дії кормової добавки “Силімевіт”

Враховуючи високу стресочутливість поросят, а також їх низьку резистентність 3 одного боку, і стресовість при вирощуванні, негативні умови утримання і недостатньо збалансовану годівлю - $з$ другого, стає зрозумілою необхідність використання кормових добавок з метою підвищення резистентності організму. Саме тому для підвищення антиоксидантного статусу організму поросят після відлучення ми використовували кормову добавку “Силімевіт”, яка у своєму складі містить суміш розмелених плодів розторопші плямистої, метіфену, селеніту натрію та вітамінів A, E i C.

Встановлено, що при згодовуванні кормової добавки “Силімевіт" у поросят на 25-у добу життя актив- ність СОД була незначно вищою за показники контрольної групи, де відповідно становила 19,58 \pm 0,82 ум. од./хв $\times$ мг білка. Вірогідне збільшення активності СОД спостерігали на 30-у добу життя, де порівняно 3 контрольною групою поросят вона зросла на 33,2 \%. На 35-у добу досліду активність супероксиддисмутази у крові дослідної групи поросят зросла на 26,9 \%, а на 40-у добу - на 24,5 \% щодо показників контрольної групи.

Супероксиддисмутаза в крові поросят як первинний антиоксидант підтримує та контролює рівень вільних радикалів, при цьому створюючи умови нормального використання кисневого середовища організму (Lavryshyn et al., 2016). Крім того, даний ензим 
успішно деактивує активні форми кисню, після розпаду яких утворюються пероксид водню. 3 цієї причини супероксиддисмутаза завжди функціонує разом 3 каталазою, яка бере участь у дезінтоксикації нерадикальної активної форми кисню, а саме $\mathrm{H}_{2} \mathrm{O}_{2}$ (Martyshuk et al., 2016; 2019; 2020; 2021).

На 25-у добу життя поросят встановлено, що каталазна активність у крові контрольної групи поросят зросла на 8,0 \%, тимчасом як у дослідної групи - на 11,6 \% порівняно 3 показниками, взятими на 20-у добу досліду. Після відлучення поросят активність каталази у крові 30-добових поросят дослідної групи була вищою на 13,3 \% порівняно 3 контролем (рис. 2). На 35-у добу досліду активність каталази у крові дослідної групи підвищилася на 41,1 \% щодо показників контрольної групи поросят. На 40-у добу досліду активність досліджуваного ензиму у крові поросят дослідної групи залишалася високою і відповідно коливалася у межах $3,88 \pm 0,12$ ммоль $/$ хв $\times$ мг білка, що на 28,9\% вище за контрольні величини.

Таким чином, згодовування поросятам дослідної групи кормової добавки “Силімевіт” сприяло підвищенню активності каталази та супероксиддисмутази у їхній крові протягом усього досліду.

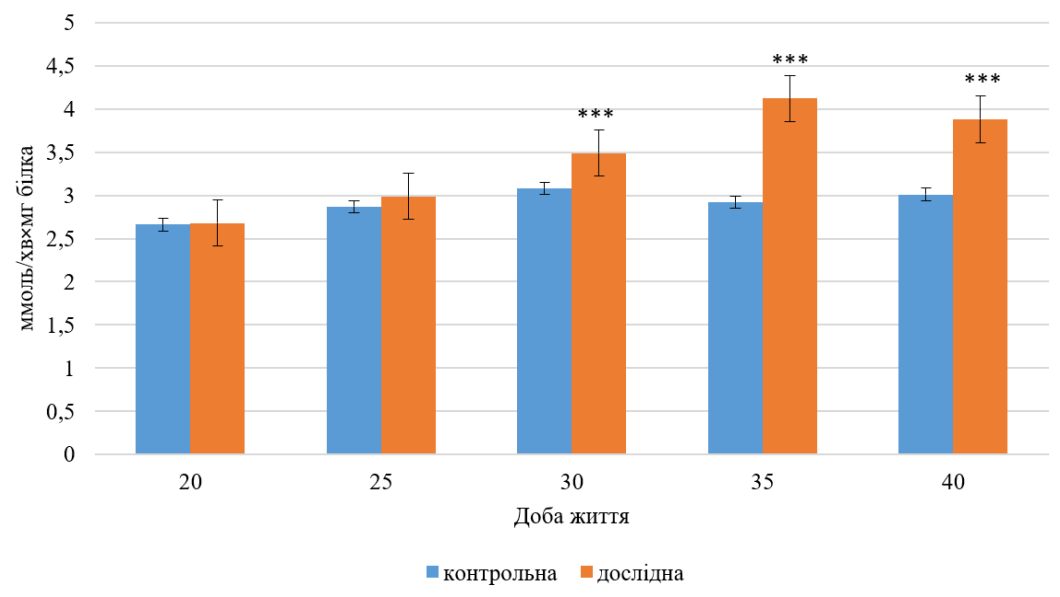

Рис. 2. Активність каталази у крові поросят за дії кормової добавки “Силімевіт”

Найважливішим показником глутатіонової системи антиоксидантного захисту $є$ глутатіон. В організмі тварин він виконує багато функцій, одними із яких $є$ захист від активних форм кисню, підтримка функції мембран, вплив на активність ензимів (Varkholiak et al., 2021). Глутатіон належить до антиоксидантів прямої дії. Він виступає донором електронів при нейтралізації активних форм кисню. На основі проведених досліджень встановлено, що у крові поросят контрольної та дослідної груп рівень відновленого глутатіону зріс відповідно на 16,7 і 63,6 \% щодо початкових величин.
Після відлучення поросят від свиноматки спостерігали зниження рівня відновленого глутатіону у крові контрольної групи поросят, тимчасом як у дослідної групи даний показник зріс у два рази. На 35-у добу життя у крові поросят дослідної групи встановлено найвищий рівень відновленого глутатіону, де порівняно з показниками контрольної групи він зріс на $75 \%$ відповідно. На 40-ву добу досліду рівень відновленого глутатіону у крові дослідної групи поросят залишався високим і відповідно становив $0,19 \pm$ 0,004 ммоль/л (рис. 3).

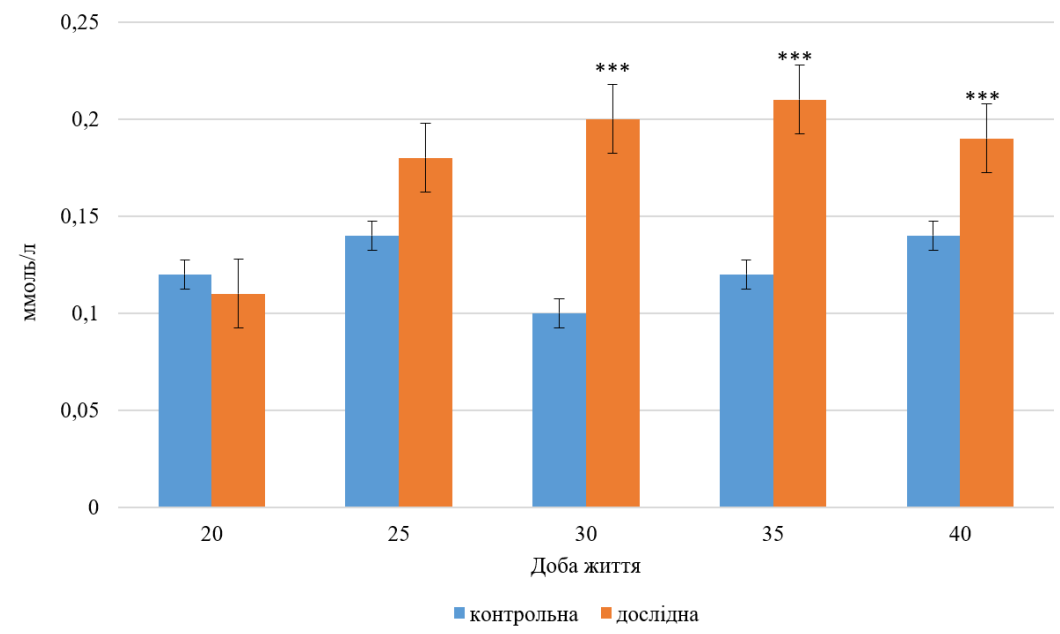

Рис. 3. Рівень відновленого глутатіону у крові поросят за дії кормової добавки “Силімевіт” 
Вільний глутатіон за участю NADPH під впливом ензиму - глутатіонпероксидази взаємодіє з активними формами кисню та інактивує токсичну дію вільних радикалів внаслідок окиснення глутатіону (Ostapyuk et al., 2021). Відновлюється окиснений глутатіон під впливом глутатіонредуктази, яка індукується за умов розвитку оксидативного стресу (Studenok et al., 2021).

При дослідженні активності глутатіонпероксидази встановлено, що у крові поросят контрольної та дос- лідної груп активність даного ензиму на 25-у добу досліду підвищилася на 16,2 і 18,6 \% порівняно 3 показниками, взятими на 20-у добу досліду. Після відлучення у поросят контрольної групи на 30-у добу досліду встановлено зниження активності ензиму відповідно на 9 \%. Найнижчою активність глутатіонпероксидази була на 35- і 40-у добу досліду, де порівняно 3 початковими величинам активність ензиму знизилася на 17,4 і 23,8 \% відповідно.

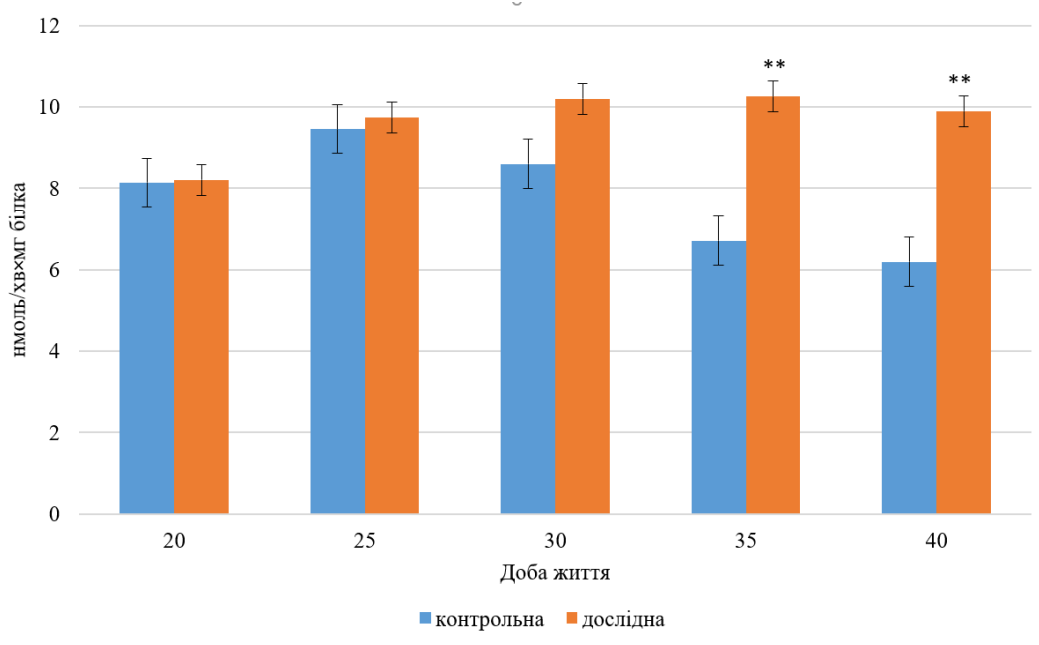

Рис. 4. Активність глутатіонпероксидази у крові поросят за дії кормової добавки “Силімевіт”

При застосуванні кормової добавки "Силімевіт" поросятам дослідної групи встановлено підвищення активності глутатіонпероксидази з 30-ї доби досліду. Так, у вказаний період досліджень активність ензиму у крові поросят дослідної групи підвищилася на 18,6 \% щодо контрольної групи поросят. На 35-у добу досліду активність глутатіонпероксидази у крові дослідної групи поросят була найвищою, де порівняно 3 контрольною групою підвищилася на 52,7 \% відповідно. На 40-ву добу досліду активність даного ензиму у крові поросят дослідної групи дещо знизилася, однак порівняно з контрольною групою залишалася високою.

При дослідженні активності глутатіонредуктази встановлено, що у крові поросят контрольної та дослідної груп на 25-у добу досліду активність даного ензиму підвищилася на 24,2 і 33,8 \% порівняно 3 початковими величинами. Після відлучення у поросят контрольної групи на 30-у добу досліду встановлено зниження активності глутатіонредуктази на 8,5 \%, на 35-у добу - на 13,4 \% і на 40-ву добу досліду - на $11 \%$ щодо показників, узятих до відлучення поросят.

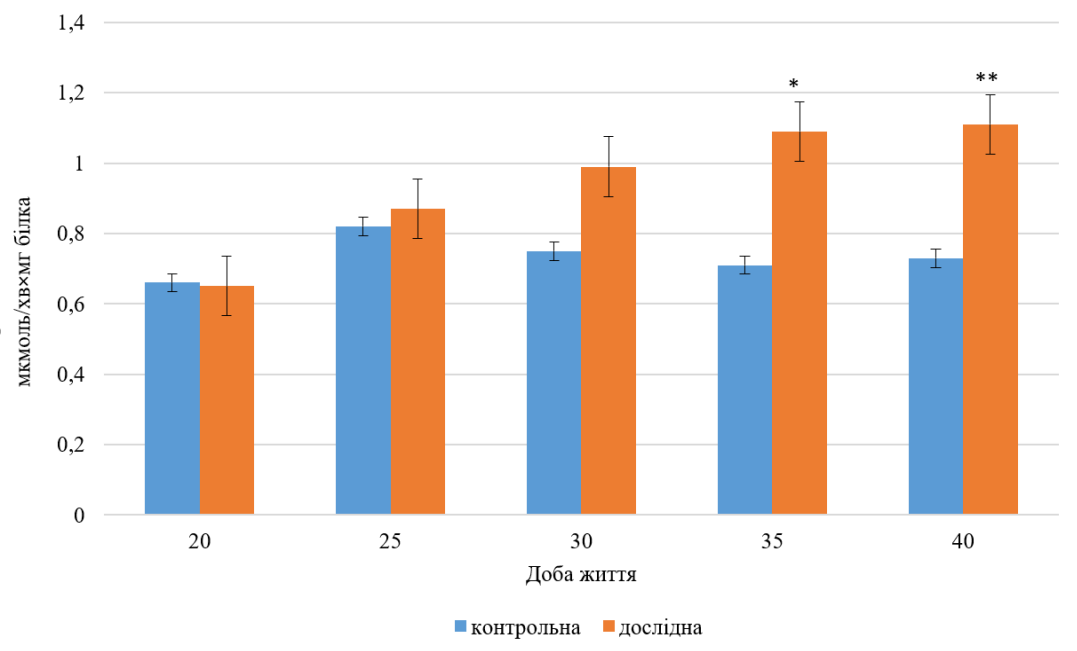

Рис. 5. Активність глутатіонредуктази у крові поросят за дії кормової добавки “Силімевіт” 
Згодовування поросятам дослідної групи кормової добавки “Силімевіт” сприяло посиленню активності глутатоінредуктази у їхній крові протягом усього досліду. Найвищою активність глутатіонредуктази у крові поросят дослідної групи була на 35- і 40-у добу досліду, де відповідно вона була вищою на 53,5 i 52,1 \% щодо показників контрольної групи.

Отже, згодовування поросятам кормової добавки “Силімевіт” сприяє посиленню їхнього антиоксидантного статусу. Застосування поросятам даної кормової добавки сприяло активізації як ензимної, так і неензимної ланки системи антиоксидантного захисту організму поросят після відлучення. Це пов'язано з тим, що до складу силімевіту входять такі діючі речовини, як розторопша плямиста та вітаміни, що $є$ сильними антиоксидантами прямої дії та безпосередньо взаємодіють 3 вільними радикалами і активними формами кисню.

\section{Висновки}

Установлено, що в умовах технологічного стресу застосування кормової добавки “Силімевіт” у кількості 100 мг/кг маси тіла на добу посилює антиоксидантний захист організму, про що свідчить підвищення в крові 35-добових поросят активності супероксиддисмутази на 26,9 \% (Р < 0,001), каталази - на 41,1\% (Р < 0,001), глутатіонпероксидази - на 52,7 \% (Р < 0,05), глутатіонредуктази - на $53,5 \%(\mathrm{P}<0,05)$, вмісту відновленого глутатіону - на $75 \%(\mathrm{P}<0,001)$.

Перспективи подальших досліджень. У перспективі планується провести дослідження щодо впливу кормової добавки “Силімевіт" на гуморальну ланку імунної системи організму поросят при відлученні.

\section{Відомості про конфлікт інтересів}

Автори стверджують про відсутність конфлікту інтересів.

\section{Подяка}

Ця робота була фінансово підтримана Міністерством освіти і науки України (0120U101999).

\section{References}

Ahmad, M. K., Amani, S., \& Mahmood, R. (2011). Potassium bromate causes cell lysis and induces oxidative stress in humanerythrocytes. Environmental Toxicology, 29(2), 138-145. doi: 10.1002/tox.20780.

Ariza-Nieto, C., Bandrick, M., Baidoo, S. K., Molitor, T. W., \& Hathaway, M. R. (2011). Effect of dietary supplementation of oregano essential oils to sows on colostrum and milk composi-tion, growth pattern and immune status of suckling pigs. Journal of Animal Science, 89(4), 1079-1089. doi: 10.2527/jas.2010-3514.

Bulter, J., Sinkora, M., \& Wertz, N. (2006). Development of the neonatal $\mathrm{B}$ and $\mathrm{T}$ cell repertoire in swine: implications for com-parative and veterinary immunology. Veterinary Research, 37(3), 417-441. doi: $10.1051 /$ vetres:2006009.
Czech, A., Smolczyk, A., \& Ognik, K. (2018). Effect of dietary supplementation with Yarrowia lipolytica or Saccharomyces cerevisiae yeast and probiotic additives on haematological parameters and the gut microbiota in piglets. Research in Veterinary Science, 119, 221-227. doi: 10.1016/j.rvsc.2018.06.007.

De Lange, C., Pluske, J. R., Gong, J., \& Nyachoti, C. M. (2010). Strategic use of feed ingredients and feed additives to stimulate gut health and development in young pigs. Livestock Science, 134(1-3), 124-134. doi: 10.1016/j.livsci.2010.06.117.

Frankic, T., Levart, A., \& Salobir, J. (2010). The effect of vitamin $\mathrm{E}$ and plant extract mixture composed of carvacrol, cinnamalde-hyde and capsaicin on oxidative stress induced by high PUFA load in young pigs. Animal, 4(4), 572-578. doi: 10.1017/S1751731109991339.

Gutyj, B., Leskiv, K., Shcherbatyy, A., Pritsak, V., Fedorovych, V., Fedorovych, O., Rusyn, V., \& Kolomiiets, I. (2017). The influence of Metisevit on biochemical and morphological indicators of blood of piglets under nitrate loading. Regulatory Mechanisms in Biosystems, 8(3), 427-432. doi: 10.15421/021766.

Gutyj, B., Martyshchuk, T., Bushueva, I., Semeniv, B., Parchenko, V., Kaplaushenko, A., Magrelo, N., Hirkovyy, A., Musiy, L., \& Murska, S. (2017). Morphological and biochemical indicators of blood of rats poisoned by carbon tetrachloride and subject to action of liposomal preparation. Regulatory Mechanisms in Biosystems, 8(2), 304-309. doi: 10.15421/021748.

Gutyj, B., Khariv, I., Khalak, V., Khariv, M., Vasiv, R., Leskiv, Kh., Martyshuk, T., \& Guta, Z. (2021). The effect of liposomal drug "Butaintervit" on the activity of the t-system of cellular immunity of rats under oxidative stress. Colloquium-journal, 22(109), 14-18. doi: 10.24412/2520-6990-2021-22109-14-18.

Han, C., Dai,Y., Liu, B. Wang, L., Wang, J., \& Zhang, J. (2019). Diversity analysis of intestinal microflora between healthy and diarrheal neonatal piglets from the same litter in different re-gions. Anaerobe, 55, 136-141. doi: 10.1016/j.anaerobe.2018.12.001.

Hedemann, M. S., \& Jensen, B. B. (2004). Variations in enzyme activity in stomach and pancreatic tissue and digesta in piglets around weaning. Archives of Animal Nutrition, 58(1), 47-59. doi: 10.1080/00039420310001656677.

Heo, J. M., Opapeju, F. O., \& Kim, J. C. (2012). Gastrointestinal health and function in weaned pigs: a review of feeding strate-gies to control post-weaning diarrhoea without using in-feed an-timicrobial compounds. Journal of Animal Physiology and Ani-mal Nutrition, 97(2), 207-237. doi: 10.1111/j.14390396.2012.01284.x.

Ivankiv, M., Kachmar, N., Mazurak, O., \& Martyshuk, T. (2019). Hepatic protein synthesis and morphological parameters in blood of rats under oxidative stress and action of feed additive "Bu-taselmevit-plus". Ukrainian Journal of Ecology, 9(4), 628-633. URL: https://www.ujecology.com/abstract/hepatic-proteinsynthesis-and-morphological-parameters-in-blood-ofrats-under-oxidative-stress-and-action-of-feed-additi44975.html. 
Jacela, J. Y., DeRouchey, J. M., \& Tokach, M. D. (2010). Feed additives for swine: Fact sheets - prebiotics and probiotics, and phytogenics. Kansas Agricultural Experiment Station Research Reports, 18(3), 132-136. doi: 10.4148/2378-5977.7067.

Khalak, V., \& Gutyj, B. (2020). Physicochemical properties and chemical composition of muscle tissue of young pigs of large white breed and their correlation with some serum enzymes. Ukrainian Journal of Veterinary and Agricultural Sciences, 3(3), 34-38. doi: 10.32718/ujvas3-3.07.

Khalak, V., Dudchak, I., Gutyj, B., Stadnytska, O., Vakulik, V., Pundiak, T., Zmiia, M., Slepokura, O., Bordun, O., \& Smyslov, S. (2021). Some biochemical indicators of serum, fattening, and meat quality of young pigs of different classes of distribution according to the Sazer-Fredin index. Ukrainian Journal of Ecology, 11(7), 6-13. doi: 10.15421/2021 236.

Khalak, V., Gutyj, B., Stadnytska, O., Shuvar, I., Balkovskyi, V., Korpita, H., Shuvar, A., \& Bordun, O. (2021). Breeding value and productivity of sows of the Large White breed. Ukrainian Journal of Ecology, 11(1), 319-324. doi: 10.15421/2021 48.

Khalak, V., Gutyj, B., Bordun, O., Ilchenko, M., \& Horchanok, A. (2020). Effect of blood serum enzymes on meat qualities of piglet productivity. Ukrainian Journal of Ecology, 10(1), 158-161. doi: 10.15421/2020 25.

Khalak, V., Gutyj, B., Bordun, O., Horchanok, A., Ilchenko, M., Smyslov, S., Kuzmenko, O., \& Lytvyshchenko, L. (2020). De-velopment and reproductive qualities of sows of different breeds: innovative and traditional methods of assessment. Ukrainian Journal of Ecology, 10(2), 356-360. doi: $10.15421 / 2020109$.

Khariv, I., Gutyj, B., Hunchak, V., Slobodyuk, N., Vynyarska, A., Sobolta, A., Todoriuk, V., \& Seniv, R. (2017). The influence of brovitatoxide in conjunction with milk thistle fruits on the immune system of turkeys for eimeriozic invasion. Scientific Messenger LNUVMBT named after S. Z. Gzhytskyj, 19(73), 163-168. doi: 10.15421/nvlvet7334.

Khariv, M., Gutyj, B., Butsyak, V., \& Khariv, I. (2016). Hematological indices of rat organisms under conditions of oxidative stress and liposomal preparation action. Biological Bulletin of Bogdan Chmelnitskiy Melitopol State Pedagogical University, 6(1), 276-289. doi: $10.15421 / 201615$.

Khariv, M., Gutyj, B., Ohorodnyk, N., Vishchur, O., Khariv, I., Solovodzinska, I., Mudrak, D., Grymak, C., \& Bodnar, P. (2017). Activity of the T- and B-system of the cell immunity of animals under conditions of oxidation stress and effects of the liposomal drug. Ukrainian Journal of Ecology, 7(4), 536-541. doi: 10.15421/2017 157 .

Kramarenko, S. S., Lugovoy, S. I., Kharzinova, V. R., Lykhach, V., Kramarenko, A. S., \& Lykhach, A. V. (2018). Genetic diversity of Ukrainian local pig breeds based on microsatellite markers. Regulatory Mechanisms in Biosystems, 9(2), 177-182. doi: 10.15421/021826.

Kramarenko, S., Lugovoy, S., Lykhach, A., Kramarenko, A., \& Lykhach, V. (2018). A comparative study of the reproductive traits and clustering analysis among different pig breeds. Scien-tific Messenger of LNU of Veterinary Medicine and Biotechnol-ogies. Series: Agricultural Sciences, 20(84), 21-26. doi: 10.15421/nvlvet8404.

Kramarenko, S., Lugovoy, S., Lykhach, A., Kramarenko, A., Lykhach, V., \& Slobodianyk, A. (2019). Effect of genetic and non-genetic factors on the reproduction traits in Ukrainian Meat sows. Scientific Messenger of LNU of Veterinary Medicine and Biotechnologies. Series: Agricultural Sciences, 21(90), 3-8. doi: 10.32718/nvlveta9001.

Lavryshyn, Y. Y., Varkholyak, I. S., Martyschuk, T. V., Guta, Z. A., Ivankiv, L. B., Paladischuk, O. R., Murska, S. D., Gutyj, B. V., \& Gufriy, D. F. (2016). The biological significance of the antioxidant defense system of animals body. Scientific Messenger LNUVMBT named after S.Z. Gzhytskyj, 18(2(66)), 100-111. doi: 10.15421/nvlvet6622.

Martyshuk, T.V., Gutyj, B.V., \& Vishchur, O.I. (2016). Level of lipid peroxidation products in the blood of rats under the influence of oxidative stress and under the action of liposomal preparation of "Butaselmevit". Biological Bulletin of Bogdan Chmelnitskiy Melitopol State Pedagogical University, 6(2), 22-27. doi: 10.15421/201631.

Martyshuk, T. V., Gutyj, B. V., Vishchur, O. I., \& Todoriuk, V. B. (2019). Biochemical indices of piglets blood under the action of feed additive "Butaselmevitplus". Ukrainian Journal of Veterinary and Agricultural Sciences, 2(2), 27-30. doi: 10.32718/ujvas2-2.06.

Martyshuk T. V., Gutyj B. V., Vishchur O. I. (2019). Morphological and biochemical indices of piglets' blood by the action of feed additive "Butaselmevitplus". The Animal biology, 21(4), 65-70. doi: 10.15407/animbiol21.04.065.

Martyshuk, T. V., Gutyj, B. V., Zhelavskyi, M. M., Midyk. S. V., Fedorchenko, A. M., Todoriuk, V. B., Nahirniak, T. B., Kisera, Ya. V., Sus, H. V., Chemerys, V. A., Levkivska, N. D., \& Iglitskej, I. I. (2020). Effect of Butaselmevit-Plus on the immune system of piglets during and after weaning. Ukrainian Journal of Ecology, 10(2), 347-352. doi: 10.15421/2020 106

Martyshuk, T. V., Gutyj, B. V., Leskiv, Kh. Ya., Semaniuk, N. V., \& Shnaider, V. L. (2021). The effect of the liposomal drug "butaselmevit" on the enzymatic and non-enzymatic part of the glutatoin system of the blood of rats under oxidative stress. Colloquiumjournal, 12(99), 16-19.

Martyshuk, T., Gutyj, B., \& Khalak, V. (2021). System of antioxidant protection of the body of piglets under the action of feed additive "Butaselmevit-plus". Ukrainian Journal of Veterinary and Agricultural Sciences, 4(2), 38-43. doi: 10.32718/ujvas4-2.07.

Ostapyuk, A.Y., Holubieva, T.A., Gutyj, B.V., \& Slobodian, S.O. (2021). The effect of sylimevit, metifen, and milk thistle on the intensity of the processes of peroxidation of lipids in the body of laying hens in experimental chronic cadmium toxicosis. Ukrainian Journal of Ecology, 11(4), 57-63. doi: $10.15421 / 2021$ 199. 
Sobolev, A., Gutyj, B., Grynevych, N., Bilkevych, V., \& Mashkin, Y. (2017). Enrichment of meat products with selenium by its introduction to mixed feed compounds for birds. Regulatory Mechanisms in Biosystems, 8(3), 417-422. doi: 10.15421/021764.

Stojanovskyj, V., \& Ogrodnyk, M. (2016). Function of intestinal immune barrier of piglets under technological stress. Scientific Messenger of LNU of Veterinary Medicine and Biotechnologies. Series: Veterinary Sciences, 18(3(71), 112-116. doi: 10.15421/nvlvet7126.

Studenok, A. A., Shnurenko, E. O., Karpovskyi, V. I., Trokoz, V. O. \& Gutyj, B. V. (2021). Indicators of protein metabolism and intensity of lipid peroxide ox- idation in chickens with different vegetative status. Scientific Messenger of Lviv National University of Veterinary Medicine and Biotechnologies. Series: Veterinary sciences, 23(102), 110-118. doi: $10.32718 /$ nvlvet10217.

Varkholiak, I.S., Gutyj, B.V., Leskiv, Kh.Ya., Kushnir, V.I., Hariv, I. I., Martyshuk, T. V., \& Guta Z. A. (2021). The effect of bendamine on antioxidant protection of rats' myocardium in doxorubicin intoxication. Colloquium-journal, 7(94), 18-21. doi: 10.24412/2520-6990-2021-794-18-21. 